\title{
Medievalista
}

Online

14 | 2013

Número 14

\section{Editorial. Orgulhosamente acompanhados}

\section{(2) OpenEdition \\ 12 Journals}

\section{Edição electrónica}

URL: http://journals.openedition.org/medievalista/342

DOI: 10.4000/medievalista.342

ISSN: 1646-740X

\section{Editora}

Instituto de Estudos Medievais - FCSH-UNL

\section{Refêrencia eletrónica}

" Editorial. Orgulhosamente acompanhados », Medievalista [Online], 14 | 2013, posto online no dia 01 julho 2013, consultado o 22 setembro 2020. URL : http://journals.openedition.org/medievalista/342 DOI : https://doi.org/10.4000/medievalista.342

Mediavalista está licenciado com uma Licença Creative Commons - Atribuição-NãoComercial 4.0 Internacional. 
Título: Editorial. Orgulhosamente acompanhados.

Autor(es): A Equipa de Redacção

Fonte: Medievalista [Em linha]. №14, (Julho - Dezembro 2013). Dir. José Mattoso.

Lisboa: IEM.

Disponível em: http://www2.fcsh.unl.pt/iem/medievalista/

ISSN: $1646-740 \mathrm{X}$

\section{Editorial.}

\section{Orgulhosamente acompanhados}

A Equipa de Redacção

$\mathrm{O}$ apelo à apresentação de artigos lançado pela Medievalista para os números 14 e 15 encontrou grande receptividade junto de estudiosos da Idade Média. De facto, chegou-nos um número muito significativo de trabalhos a submeter a arbitragem científica, com vista à sua publicação. Daí que, apesar de incluirmos agora um conjunto mais vasto de artigos do que é habitual, tenha ainda transitado para o próximo número um considerável leque de propostas recebidas pela Redacção. 
A quantidade e a qualidade dos estudos que nos chegam e que são submetidos a arbitragem científica ilustram bem o alargamento da audiência de uma revista especializada que desde o seu início, em 2005 e sob a direcção de Luís Krus, sempre teve a ambição de se tornar num veículo de comunicação entre medievalistas, muito para além das fronteiras nacionais. Essa orientação tem sido mantida pela Redacção e pelos directores que se sucederam, e constitui um imenso estímulo verificar que tal objectivo tem vindo a ser cumprido, com o que isso significa de crescente reconhecimento do papel e do prestígio da Medievalista.

Tal como o anterior, também o presente número volta a reflectir essa realidade, com uma elevada colaboração de autores portugueses e estrangeiros. Merece "Destaque" o trabalho de Hilário Franco Júnior sobre o pensamento analógico da Idade Média. A secção de "Artigos" inclui estudos de Juan Carlos Arboleda Goldaracena sobre caridade e cristianismo na Andaluzia dos finais da Idade Média, de Sofia Lovegrove Pereira sobre a igreja de Santa Maria de Júnias, de Vera Santos sobre a necrópole rupestre do Alto do Calvário em Miranda do Corvo, de Luís Gethsemaní Pérez Aguilar sobre aspectos metodológicos do estudo do mundo rural andaluz, de Alejandro García Morilla sobre inscrições do convento de San Vicente de Villamayor de los Montes e de Anna Dzialak sobre Richeza, uma rainha polaca do século XI. Maria Leonor Botelho faz a recensão da dissertação de doutoramento de Maria Amélia Álvaro de Campos sobre Santa Justa de Coimbra, Elaine Cristine Farrell apresenta a sua tese de doutoramento defendida na Universidade de Dublin sobre conversão ao cristianismo e religião popular na Alta Idade Media irlandesa e Eduardo Henrik Aubert desenvolve uma oportuna reflexão em torno de um recente colóquio dedicado ao tema Pourquoi étudier le Moyen Âge au XXI siècle?, cujas actas vieram a lume em 2012. Finalmente, a rubrica Varia insere ainda uma desenvolvida notícia da autoria de Alicia Miguélez Cavero e de Maria Alessandra Bilotta sobre a Conferência Internacional "Medieval Europe in Motion", que teve lugar em Lisboa em Maio deste ano.

Num momento em que pairam incertezas sobre o presente e o futuro do Sistema Científico português e, nomeadamente, sobre a área das Ciências Sociais e das Humanidades, com as já conhecidas restrições orçamentais e com as anunciadas mudanças no figurino de financiamento das Unidades de Investigação, a Medievalista mantém o seu curso de procura do rigor e da qualidade historiográfica. Rigor que 
começa no respeito de uma estrita regularidade semestral; qualidade historiográfica que está patente no nível dos colaboradores e dos artigos publicados. Rigor e qualidade que, sendo objectivos últimos em si mesmos, constituem também a via que traçámos para projectar internacionalmente o medievalismos português.

Neste percurso, com os muitos nacionais ou estrangeiros que têm seguido o trajecto da Medievalista, com aqueles que connosco têm colaborado e nos confiam os seus trabalhos, com os que compreendem a importância de uma revista científica e interdisciplinar, aberta, actualizada e crítica, especializada em estudos medievais e editada em Portugal mas reconhecida internacionalmente, com esses e com muitos mais a quem queremos chegar no futuro próximo, tudo faremos para continuarmos orgulhosamente acompanhados.

\section{COMO CITAR ESTE ARTIGO}

\section{Referência electrónica:}

"Editorial. Orgulhosamente acompanhados". Medievalista [Em linha].

No14, (Julho - Dezembro 2013). [Consultado dd.mm.aaaa]. Disponível em

http://www2.fcsh.unl.pt/iem/medievalista/MEDIEVALISTA14/editorial1401.html.

ISSN 1646-740X.

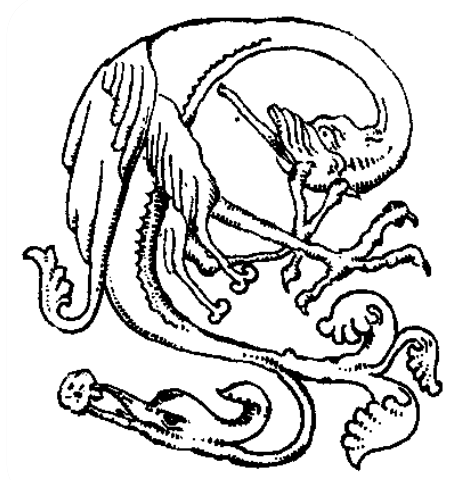

Medievalista online $N^{0} 14 \mid$ Julho - Dezembro 2013 ๑ IEM - Instituto de Estudos Medievais 3 www2.fcsh.unl.pt/iem/medievalista 